\title{
Factors Challenging the Zeal of Students for Learning: The Nigerian Example
}

\author{
Ugochi Ukamka Ugwu \\ School of Sciences and Maths, The College of Education, Nsukka, Enugu State, Nigeria
}

\begin{abstract}
Education is one of the strategies for the development of any nation. Therefore, many nations, governments, including organizations are keen on achieving the Sustainable Development Goal (SDG) 4; which addresses universal basic education. A review of the Nigerian teaching strategy signified a consistent depreciating paradigm which could be attributed to some factors. Despite these factors, there is the belief that the quality of Nigerian education would not have gone down to its present appalling state if students were passionate about learning. A review of literature also showed a paucity of information for understanding the factors challenging the zeal/passion of students for learning. Therefore, this paper aims to fill this gap in knowledge by highlighting these factors and the extent of the decay in the system. A survey design was used to elicit data from a sample of 160 senior secondary school students. Data were collected using a self-structured questionnaire. Mean, Standard Deviation, median, and Mann Whitney U test were used to test and analyze students' responses. The results showed that factors including weak education foundation and payment for examination malpractice challenged students zeal for learning. The study made suggestions and concluded that these factors need to be considered before SDG4 can be achieved in Nigeria.
\end{abstract}

Keywords: Sustainable Development Goals, Nigeria, learning, students, senior secondary schools

DOI: $10.7176 / \mathrm{JEP} / 10-17-05$

Publication date: June $30^{\text {th }} 2019$

\section{Introduction}

Recognizing education as one of the strategies for development, the United Nations (UN) included it as one of the sustainable development goals (SDG 4) which they hope to achieve by 2030. The overall aim is to support inclusive and equitable quality education and promote lifelong learning opportunities for all by 2030. To this effect, UN has mapped out some strategies which will help in the achievement of the SDG 4; and an appeal to advanced countries to set out funds (Scholarship) to sponsor higher education students from emerging economies (https://en.unesco.org/gem-report/sdg-goal-4).Therefore, the onus of learning for school students lies in the ability of each country to create a conducive environment for her students.

Student learning in our contemporary digital world can be quite exciting and challenging at the same time. Exciting because many students are among those called "the digital natives" (people born after the year 1980) according to Prensky (2001). An idea that has gained support concerning this generation of people is that they grew up with access to computers and the Internet, and are,therefore, inherently technology-savvy (Littlejohn\&Vojt, 2011; Oblinger\&Oblinger, 2005; Palfrey \& Gasser, 2008; Prensky, 2001; Tapscott, 1998 in Margaryan, Littlejohn \&Vojt, 2011). The proponents of this idea claim that not only does this generation have sophisticated skills in using digital technologies; they have also developed radically new cognitive capacities and learning styles through their exposure to these technologies. However, these proponents noted that some challenges are affecting digital learning in our contemporary society.

With regards to the challenges of learning in a digital world, these proponents also claim that the current education system is not equipped to accommodate the changing needs of this new generation of learners and call for "widespread discussion among members of the academy about the trends (Dede, 2005b and Margaryan, Littlejohn \&Vojt, 2011). In the same light, some school of thoughts worry that this new generation of students may be incapable of deeper learning and productive work (Bauerlein, 2008); while others take an optimistic view of the skill-set these learners are developing but claim that "educators are failing them by not adapting instruction to their needs" (Prensky, 2001b, p. 442, 2001c; Rosen, 2010; Tapscott, 2009, p. 368 in Thompson, 2013). Such a scenario is worsened and multiplied in emerging economies.

In some emerging economies including Nigeria, learning in schools level has depreciated to the extent that some high school graduates cannot compete with their counterparts in advanced countries such as Australia, Canada, United States of America and the United Kingdom. Gbenu (2012) contends that the quality of education offered in these advanced countries is such that makes recipients creators of jobs rather than jobseekers. Whereas, the opposite is the case in Nigeria, where unemployed graduates outnumber their employed counterparts with about $60 \%$. Similarly, Ike (2017) asserted that in Nigeria, the qualities of students who graduate from secondary school level over the years have continued to dwindle.Thus, Thom-otuya,\&Inko-tariahthe (2016) contend that the situation of Nigerian education system and quality is becoming worrisome as her education policy is more focused on quantitative rather than the qualitative aspect of institutional development. 
To this end, the problems of the Nigerian education sector have their roots in what may be described as a complex mix of economic, political, and social situations (Garba, 2012). These problems have been attributed to factors such as unstable Staff, inadequate classroom accommodation, poorly equipped libraries, laboratories and subject room, poor preparation and examination malpractices, poor parenting/guidance and poverty level (Ike 2017)). Olaguro (2018) also observed that the tragedy in having untrained, unqualified and other impostors who have no business with chalk lies at the foundation of the many problems the Nigerian education system faces. For Olagboye (2004), some of the challenges of education in Nigeria include

1. Supervisors lack training in supervisory competencies because some were promoted based on seniority and length of service but not appropriate training and qualification.

2. Inadequate provision of infrastructural facilities, teaching aids and instructional materials in schools.

3. Poor remuneration of teachers and poor conditions of service, which reduces commitment to teaching.

4. The poor status accorded to teachers, which dampen their morale and job satisfaction.

5. Presence of a large number of untrained and unqualified teachers in the school system.

6. Teachers' poor attitude to work and lack of interest in teaching.

\section{Statement of the Problem}

Education is at the centre of the training of responsible citizens and the development of nations with progressive intentions. As Ugwu (2018) put it, characterized by teaching and learning, education is essential to the development of any nation. As such, schools, organizations and governments of many advanced countries invest heavily in their education sector to support standard teaching, which could compete globally. According to Malcolm X in Olaguro (2018), education is the passport to the future, for tomorrow belongs to those who prepare for it today. Umoh (2016) noted that

\section{education helps individuals to develop physically, mentally,} morally, spiritually and emotionally by providing a suitable environment, teaching them new knowledge, attitudes, and skills that will enable them to be useful to themselves and their society.

Thus, the educational standards set up must be challenging to meet the needs of the students and the society (Olaniyonu, Adekoya and Gbenu, (2008)

Despite the importance of education to the development of every nation, as highlighted in the literature, the Nigerian education system continues to depreciate significantly. The situation is worrisome at the primary and secondary school levels where there are many dilapidated buildings, with the education stakeholders in the country recruiting more unqualified personnel to teach students. The anomaly has been attributed to factors which include poor funding of education sector, unqualified teachers, inadequate teaching and learning facilities, overpopulation of students in a class estimated to 60-100, lack of workshops/conferences for teachers knowledge updates and unqualified people heading the education sector.

Besides these challenges above that work against the Nigerian education system, there is also the issue of "students' learning zeal/passion," which many researchers have not discussed in earlier researches. A school of thought believes that despite the odds stacked against sustained learning in a country like Nigeria, a student can achieve learning if only he/she is passionate enough. As an educationist, the researcher found that many Nigerian secondary school students no longer have a passion for learning. Rather than learn, they prefer to do menial jobs, save up money and buy their way out of senior school examinations. This trend implies that even with the targets set in SDG4 by the UN, Nigeria may not achieve quality education for all her citizens, except the education stakeholders in the country come up with practical strategies for arousing the passion of students for learning. Thus, this paper aims to identify and discuss the factors that challenge students' zeal for learning in Nigerian secondary schools.

\section{Purpose of the Study}

The overall purpose of this study is to determine the factors that challenge students zeal for learning in Nigerian secondary schools. Specifically, the study seeks to understand:

1. The factors that challenge students' zeal for learning in Nigerian secondary schools

2. The extent these factors challenge students' zeal for learning in Nigerian secondary schools

\section{Research Questions}

These research questions were raised to guide the study:

1. What factors challenge challenge' zeal for learning in Nigerian secondary schools? 
2. To what extent do the factors challenge students' zeal for learning in Nigerian secondary schools?

\section{Hypotheses}

The following null hypotheses were tested at 0.05 level of significance

HO 1 : The distribution of responses for boys and girlson the factors that challenge students zeal for learning in Nigerianschools are the same

$\mathbf{H O}_{2}$ : The distribution of responses for boys and girls on the extent to which these factors challenge students' zeal for learning in Nigerian secondary schools are the same

\section{Methodology}

This study adopted a descriptive survey research design to undertake the research. Nsukka Education Zone of Enugu State, Nigeria was selected as the case study site. The population of the study comprised 1582 senior secondary three (SS3) students from the 64 public secondary schools within Nsukka Education Zone of Enugu State. Proportionate purposive random sampling methods were used to obtain a sample size of 160 studentrespondents from 12 secondary schools (four mixed schools from each of the three development centres) within the zone. A structured questionnaire was used to collect data from the research participants. Cronbach alpha method was used to determine the internal consistency of the items in the questionnaire and the reliability was 0.79. The researcher made use of mean, standard deviation, and median to address the two questions guiding the research. Hypotheses were analyzed and tested statistically using the Mann-Whitney U Test via Statistical Package for Social Sciences (SPSS) version 16.0

\section{Results of the research}

1. Research question 1: What are the factors that challenge students' zeal for learning in Nigerian secondary schools?

The presentation in table 1 indicates that weak education foundation (mean: 3.52 , median: 4 , and P value: 0.84 ), lack of reading time at home (mean: 3.46, median: 3 , and P: 0.33 ), fatigue because of too many house chores (mean: 3.12, median: 3, and P: 0.48), hunger (mean: 3.33, median: 3, and P: 0.11), digital technology (mean: 3.20, median: 3, and P: 0.42), low self esteem (mean: 3.01, median: 3, and P: 0.43), payment for external exam malpractice (mean: 2.89, median: 3, and P: 0.36), fear of unemployment of graduates (mean: 3.40, median: 3 , and P: 0.48 ), insufficient reading time at school (mean: 3.03, median: 3 , and P: 0.34 ), truancy by teachers (mean: 2.91, median: 3, and P: 0.65) and inadequate learning facilities (mean: 3.06, median: 3, and P: 0.57) are factors challenging the zeal of students for learning in Nsukka Education zone of Enugu State, Nigeria. The results also depict that the distribution of responses for boys and girls on these factors are the same

2. Research Question 2: To what extent do these factors challenge students zeal for learning in Nigerian secondary schools?

Data presented in Table 2 show that to a great extent, weakeducation foundation (mean: 3.28 , median: 3 , and P: 0.44 ), lack of reading time at home (mean: 3.03, median: 3 , and P: 0.41 ), fatigue because of too many house chores (mean: 3.03, median: 3, and P: 0.72), hunger (mean: 2.98, median: 3, and P: 0.86), digital technology (mean: 3.10, median: 3, and P: 0.78), low self esteem (mean: 3.03, median: 3, and P: 0.74), payment for external exam malpractice (mean: 3.42, median: 3, and P: 0.39), fear of unemployment of graduates (mean: 2.69, median: 3, and P: 0.00), insufficient reading time at school (mean: 3.27 , median: 3 , and P: 0.13 ), truancy by teachers (mean: 3.34, median: 3, and P: 0.51) and inadequate learning facilities (mean: 3.23, median: 3, and P: 0.70) challenge the zeal of students for learning. Results also signify that the distribution of responses for boys and girls on the extent to which these factors challenge students' zeal are the same except for item 21 which showed a significant difference (p: 0.00).

\section{Discussion}

Factors that challenge the zeal of students for learning in Nigerian secondary schools

The findings of this study have some exciting outcomes. From the results, some salient points were noted and these include the following:

(i) Many students lack the necessary academic foundation from primary school and as such, find it difficult to follow up with learning at the secondary level. The implication is that the students become confused and end up not having the zeal for their studies. This finding is consistent with the findings of other scholars who have worked on a similar topic. They include Ijeoma (2004), Adedeji (2004), Onyeagba (2006), Saidu (2008) in Sen (2010) and Etor, Mbon \& Ekanem (2013) who noted that primary education is the foundation for a child's learning upon which every other level of learning depends.

(ii) There is little or no time for students to read at home and in school. The former is because of many chores in the house and also working menial jobs to feed. The latter is because many public secondary schools overcrowd their school time with teaching and no free period for the students to study on their own and digest 
what was taught.This makes the students fail their examinations continuously and in so doing lose interest in education. This finding supports the report from https://www.renaissance.com/2018/01/23/blog-magic-15minutes-reading-practice-reading-growth/ which noted thus:

An analysis comparing the engaged reading time and reading scores of more than 2.2 million students found that students who read less than five minutes per day saw the lowest levels of growth, well below the national average. Even students who read 5-14 minutes per day saw sluggish gains that were below the national average. Only students who read 15 minutes or more a day saw accelerated reading gains - that is, gains higher than the national average-and students who read just over a half-hour to an hour per day saw the greatest gains of all.

(iii) Many Nigerians suffer from hunger, and the resultant effect is that some students come to school without eating breakfast and equally go home after school to work before having lunch. Because of this, these students utilize most of their time (school time inclusive) doing menial jobs than coming to school and in so doing, become disinterested in learning because they have the primary goal of first finding a means for survival. This finding is similar to the report from 2017 research by 'No Kid Hungry'retrieved from https://education.cuportland.edu/blog/classroom-resources/hunger-pains-teaching-hungry-students/ which noted "that in our nation's suburbs, urban areas, and rural towns, over 13 million children from low-income families go to school hungry". (iv) Many students are so inclined to their phones to the extent that they cannot stay about two hours without visiting social media platforms. They prefer to live in the fantasy of social media than being passionate about their studies. This finding is in line with the opinions of Davidovitch \&Yavich (2018) that the average duration of daily usage of smartphones for students in ages between 12 and 17 is three to four hours.

(v) Some students suffer from low self-esteem because of physical and emotional abuse at home and in school, which affects their zeal to learn. Llyod's (2018) view supports this finding that the 'toxic trio' of domestic violence, substance misuse, and parental mental health problems can render children at risk of harm and complex trauma.

(vi) Students pay supervisors to allow them to indulge in malpractice during examinations and because of this, they think that it is a waste of time to sit down, study and learn since they can buy their way to excellent results. The implication is that even the few students who are passionate about learning become disinterested and join the trend as their colleagues and even the supervisors harass them during examinations. Onyibe, Uma \& Ibin (2015) supported this observation when they contend that a student may pay an examination official some money not necessarily to buy the question paper but to be allowed to use illegal materials smuggled into the examination halls or to extend the examination scheduled period.

(vii) Students are afraid of getting jobs because of the level of unemployment for graduates in Nigeria. Students think that it is a waste of precious time and resources acquiring knowledge since many graduates are jobless. So, they become dispassionate about learning and dedicate their time to alternative ways of making quick money. In line with this finding, Simon and Alfred (2008) in Longe (2017) commented that rampant unemployment of university graduates is not only a disincentive to schooling, but could also be a recipe for social unrest, if not checked.

(viii) Some teachers are nonchalant about their jobs because of the meager salary they earn. These teachers look for other ways to make money, and by so doing, engage in truancy. Students are always at the mercy of such teachers who often do not show up at their duty post in the school. This ugly scenario implies that most times, students receive few lessons in a day. The frequency of this occurrence keeps them off school and equally leads to their lack of zeal for learning. This finding is in agreement with the research findings published by UNESCO in 2014 and retrieved from https://www.newtimes.co.rw/section/read/187851. The report noted that the quality of education improves when teachers are given all the support needed, and this includes their income and other incentives to encourage them to remain in the field of teaching. The report added that it is through this means that students will get what they require as far as education is concerned.

(ix) Many public schools lack adequate learning facilities such as dilapidated buildings, instructional materials and qualified teachers. An example would be one of the schools which the researcher visited. It was observed that students were beaten by rain because of the absence of windows, doors and classroom walls. Another example showed about 95 students in one class clamoring for one computer during a practical computer class. Some students who could not compete against these odds lost the zeal for learning and ceased coming to school. The few students who continued to come to school only do so to fulfill an obligation and tend to become passive during classes. This finding supports the point made byAsodike \& Ikpitibo (2014) who averred that a typical scene at public school environments is that of half completed or dilapidated and overcrowded classrooms, lacking essentialequipment and facilities with unsightly and unhygienic toilet.

(x) The $\mathrm{P}$ values for the factors that challenge students zeal range from 0.11 to 0.84 and are above the 0.05 level of significance. Thus, the distribution of responses for boys and girls on these factors are the same. 
The extent to which these factors challenge the zeal of students towards learning in Nigerian secondary schools

The findings from the second research question also revealed some insightful points. These include the following: (i) Weak education foundation, lack of reading time at home, fatigue because of many house chores, hunger, digital technology, low self-esteem, payment for exam malpractice, fear of unemployment, insufficient reading time at school, truancy by teachers and inadequate learning facilities, to a high extent challenge the zeal of students for learning in many Nigeria schools, especially at the secondary level.

(ii) Except for item 21 which showed a significant difference, the $\mathrm{P}$ values for the extent to which these factors challenge students' zeal range from 0.13 to 0.86 and these are above the 0.05 level of significance. Thus, the distribution of responses for boys and girls on the extent to which these factors challenge students' zeal for learning in Nigerian secondary schools are the same.

\section{Conclusion and Recommendations}

The results of this study showed that many factors, to a great extent challenge the zeal of students for learning in Nsukka Education Zone of Enugu State, Nigeria. The findings imply that these factors are likely also to challenge secondary school students' zeal for learning in other areas and states within Nigeria because these factors are not peculiar to Nsukka area of Enugu State. The factors transcend to other places in the country. In essence, these factors are not contextualized but are national issues that demand urgent attention if the Nigerian education system is to be revamped.

From the findings, it can be concluded that students in public secondary schools in Nsukka area of Enugu State, Nigeria do not have the zeal to learn because of factors such as weak education foundation and lack of reading time at home. This scenario accounts for the reason many secondary school graduates have excellent certificates but lack basic knowledge of different subjects. Therefore, the researcher maintains that even if the challenges affecting the Nigerian education system are addressed, Nigeria might not achieve SDG4 by 2030 if nothing is done to arouse the zeal of secondary school students towards learning. Therefore, both the government and other education stakeholders in the country should get more practical in addressing the problem of students' lack of interest in learning.

Thus, to address the problem of loss of zeal/passion in learning, it is recommended that examination malpractice be curbed from the education system so that students can brace up to either reading to pass or not reading and preparing to fail. The government should introduce laws to ensure that her citizen should have a defendable academic qualification before either going for trade or entering the university. As much as possible, the government should also genuinely introduce free tuition (not in paper only) and textbooks in secondary schools to help ease the pains for most parents. The government should try and minimize the rate of unemployment of graduates in the country to improve students' psychological thinking about their future. Teachers should be empowered and their salaries improved to avoid truancy. A daily one-hour free period should be made compulsory in all schools in the region to support students to have reading time for themselves. Adequate learning facilities and counseling sessions should be made available to all schools.

\section{References}

Asodike, J. D., \& Ikpitibo, C. L. (2014). Basic issues in primary education delivery in Nigeria. European Scientific Journal, ESJ, 8(1)

Bauerlein, M. (2008). The dumbest generation: How the digital age stupefies young Americans and jeopardizes our future. New York: Jeremy P. Tarcher.

Davidovitch, N. \& Yavich, R. (2018). Usage of mobile phone applications and its impact on teaching and learning. International Journal of Higher Education, 7(1), 1-9.

Etor, C., Mbon, U. \& Ekanem, E. (2013). Primary education as a foundation for qualitative higher education in Nigeria. Journal of Education and Learning, 2(2), 155-164.

Garba, .A. (2012). Secondary education in Nigeria: A synthesis of basic student-specific concerns from guidance and counselling perspective. Journal of International Cooperation in Education, 15,.2, 195-205

Gbenu, J. P. (2012). State of Nigerian secondary education and the need for quality sustenance. Greener journal of educational research, 2(1), 7-12.

Gunn, J. (2018). Hunger pains: Teaching hungry students. [online] Available: https://education.cuportland.edu/blog/classroom-resources/hunger-pains-teaching-hungry-students/

Ike, P. Problems and prospects of secondary education in Nigeria. International Journal of Education and Evaluation, ISSN, 2489-0073.

Lloyd M. (2018). Domestic violence and education: Examining the impact of domestic violence on young children, children, and young people and the potential role of schools. Frontiers in psychology, 9.

Longe, O. (2017). Graduate unemployment in Nigeria: Causes, consequences and remediable approaches. American International Journal of Contemporary Research, 7(4), 63-73. 
Margaryan, A., Littlejohn, A. \&Vojt, G. (2011). Are digital natives a myth or reality? University students' use of digital technologies. Computers \& education, 56(2), 429-440.

Olagboye, A. (2004). Introduction to educational management in Nigeria. Published for Kemsio Educational Consultants by Daily Graphics (Nigeria).

Olaguro, M. (2018). Is the shambolic state of Nigeria's education a consequence of a dearth of policies? [online]. Available: $\quad$ http://saharareporters.com/2018/09/29/shambolic-state-nigeria\%E2\%80\%99s-educationconsequence-dearth-policies-modiu-olaguro (September 29, 2018).

Onyibe, C., Uma, U.\& Ibina, E. (2015). Examination malpractice in Nigeria: Causes and effects on national development. Journal of Education and Practice, 6(26), 12-17.

Olaniyonu, S., Adekoya, S., \& Gbenu, J. (2008). Fundamentals of educational planning (revised and enlarged). Lagos: Micodex.

Prensky, M. (2001). Digital natives, digital immigrants part 1. On the horizon, 9(5), 1-6.

Sen, A. (2010). Primary schooling in West Bengal. Prospects quarterly review of comparative education, 155(3), 311-320.

The Magic of 15 minutes: Reading practice and reading growth. [online]. Available: https://www.renaissance.com/2018/01/23/blog-magic-15-minutes-reading-practice-reading-growth/

Thom-otuya, B. \& Inko-tariah, D. (2016). Quality education for national development: The Nigerian experience. African Educational Research Journal, 4(3), 101-108.

Thompson, P. (2013). The digital natives as learners: Technology use patterns and approaches tolearning. Computers \& Education, 65, 12-33.

Times Reporter. (2015). Does teachers' pay have any impact on quality of education? [online]. Available: https://www.newtimes.co.rw/section/read/187851 (April 15, 2015).

Umoh, G. (2006). Path to quantitative education: A standard book for students, teachers andeducational administrators. Uyo: Inela Ventures and Publishers.

\section{Appendix}

Table 1: factors that militate against students zeal for learning in Nigerian secondary schools

\begin{tabular}{|c|c|c|c|c|c|c|c|}
\hline $\mathbf{S} / \mathbf{N}$ & $\begin{array}{l}\text { Item Statements } \\
\text { As a secondary school student, my zeal to } \\
\text { learning is militated by: }\end{array}$ & $\mathbf{X}$ & $\begin{array}{l}X \\
\text { Decision }\end{array}$ & SD & Median & $\begin{array}{c}P \\
\text { Value }\end{array}$ & $\begin{array}{l}\text { P Value } \\
\text { Decision }\end{array}$ \\
\hline 1 & poor education foundation & 3.52 & A & 0.62 & 4.00 & 0.84 & NS \\
\hline 2 & lack of reading time at home & 3.46 & A & 0.58 & 3.00 & 0.33 & NS \\
\hline 3 & Fatigue as a result of too many house works & 3.12 & A & 0.69 & 3.00 & 0.48 & NS \\
\hline 4 & Hunger & 3.33 & A & 0.62 & 3.00 & 0.11 & NS \\
\hline 5 & Smartphone / social media technology & 3.20 & A & 0.78 & 3.00 & 0.42 & NS \\
\hline 6 & $\begin{array}{l}\text { Low self-esteem as a result of bullying from } \\
\text { students }\end{array}$ & 3.01 & A & 0.78 & 3.00 & 0.43 & NS \\
\hline 7 & Lack of motivation by parents / teachers & 2.95 & A & 0.77 & 3.00 & 0.34 & NS \\
\hline 8 & $\begin{array}{l}\text { Payment for external examination } \\
\text { malpractice }\end{array}$ & 2.89 & A & 0.94 & 3.00 & 0.36 & NS \\
\hline 9 & Fear of unemployment of graduates & 3.40 & A & 0.58 & 3.00 & 0.48 & NS \\
\hline 10 & Insufficient reading time at school & 3.03 & A & 0.76 & 3.00 & 0.34 & NS \\
\hline 11 & Truancy from teachers & 2.91 & A & 0.68 & 3.00 & 0.65 & NS \\
\hline 12 & Inadequate learning facilities & 3.06 & A & 0.82 & 3.00 & 0.57 & NS \\
\hline
\end{tabular}


Table 2: The extent to which the factors militate against students zeal for learning in Nigerian secondary schools

\begin{tabular}{|c|c|c|c|c|c|c|c|}
\hline $\mathbf{S} / \mathbf{N}$ & $\begin{array}{l}\text { Item Statements } \\
\text { As a secondary school student, to what } \\
\text { extent do these factors militate against my } \\
\text { zeal to learning: }\end{array}$ & $\mathbf{X}$ & $\begin{array}{l}\text { X } \\
\text { Decision }\end{array}$ & SD & Median & $\begin{array}{c}P \\
\text { Value }\end{array}$ & $\begin{array}{l}\text { P Value } \\
\text { Decision }\end{array}$ \\
\hline 13 & poor educational foundation & 3.28 & $\mathrm{HE}$ & 0.58 & 3.00 & 0.44 & NS \\
\hline 14 & lack of reading time at home & 3.03 & $\mathrm{HE}$ & 0.75 & 3.00 & 0.41 & NS \\
\hline 15 & Fatigue as a result of too many house chores & 3.03 & $\mathrm{HE}$ & 0.89 & 3.00 & 0.72 & NS \\
\hline 16 & Hunger & 2.98 & $\mathrm{HE}$ & 0.89 & 3.00 & 0.86 & NS \\
\hline 17 & Smartphone / social media technology & 3.10 & $\mathrm{HE}$ & 0.64 & 3.00 & 0.78 & NS \\
\hline 18 & Low self esteem & 3.03 & $\mathrm{HE}$ & 0.87 & 3.00 & 0.74 & NS \\
\hline 19 & Lack of motivation by parents / teachers & 3.06 & $\mathrm{HE}$ & 0.62 & 3.00 & 0.37 & NS \\
\hline 20 & Payment for external examination malpractice & 3.42 & $\mathrm{HE}$ & 0.63 & 3.00 & 0.39 & NS \\
\hline 21 & Fear of unemployment of graduates & 2.69 & $\mathrm{HE}$ & 0.76 & 3.00 & 0.00 & $\mathrm{~S}$ \\
\hline 22 & Insufficient reading time at school & 3.27 & $\mathrm{HE}$ & 0.64 & 3.00 & 0.13 & NS \\
\hline 23 & Truancy from teachers & 3.34 & $\mathrm{HE}$ & 0.63 & 3.00 & 0.51 & NS \\
\hline 24 & Inadequate learning facilities & 3.23 & $\mathrm{HE}$ & 0.69 & 3.00 & 0.70 & NS \\
\hline
\end{tabular}

